\title{
POWER RIPPLE REDUCTION OF DPC DFIG DRIVE USING ANN CONTROLLER
}

\author{
Habib BENBOUHENNI*, Abdelkader BELAIDI*, Zinelaabidine BOUDJEMA ${ }^{* *}$ \\ *Laboratoire d'Automatique et d'Analyse des Systèmes (LAAS), Departement de Génie Électrique, Ecole Nationale Polytechnique \\ d’Oran Maurice Audin, Oran, Algeria, tel.+213 663956329, E-mail: habib0264@gmail.com, belaidiaek@gmail.com \\ ${ }^{* *}$ Labo. LGEER, Electrical Engineering Department, Hassiba Benbouali University, Chlef, Algeria, \\ E-mail: boudjemaa1983@yahoo.fr
}

\begin{abstract}
Over the past years, many kinds of control strategies is proposed for doubly fed induction generators drives. Among them, direct power control (DPC) has gained more importance due to simple control structures and fast dynamic response. However, it has a disadvantage of high ripples in active power, reactive power, and slow response because of hysteresis controllers in active and reactive. To improve the performance of DPC and to reduce the active and reactive powers ripples, DPC based artificial neural network (ANN) controller is proposed in this work. The simulation is carried out using Matlab/Simulink and compares the proportional-integral (PI) controller and in DTC artificial neural is implemented and simulated results are shown.
\end{abstract}

Keywords: $D P C, A N N, P I, D T C$, reactive power, active power.

$\begin{array}{ll}\text { NOMENCLATURE } \\ \text { DFIG } & \text { Doubly fed induction generator. } \\ \text { SFO } & \text { Stator Failed orientated. } \\ \text { DPC } & \text { Direct power control. } \\ \text { PI } & \text { Proportional integral } \\ \text { SVM } & \text { Space vector modulation. } \\ \text { ANN } & \text { Artificial neural network. } \\ \text { IG } & \text { Induction generator. } \\ \text { THD } & \text { Total harmonic distortion. } \\ \text { SVPWM } & \text { Space vector pulse width modulation. } \\ \text { MPPT } & \text { Maximum power point tracking. } \\ \text { RSC } & \text { Rotor side converter. } \\ \text { GSC } & \text { Grid side converter. } \\ P s & \text { Active power. } \\ Q s & \text { Reactive power. } \\ V s, V r & \text { Stator and rotor voltages. } \\ I s, I r & \text { Stator and rotor currents. } \\ \psi s, \psi r & \text { Stator and rotor fluxes. } \\ p & \text { Number of pole pairs. } \\ R s, R r & \text { Stator and rotor resistances } \\ L s, \text { Lr } & \text { Stator and rotor self-inductances } \\ L m & \text { Mutual inductance. } \\ \Omega & \text { Angular speed of the turbine. } \\ J & \text { Inertia. } \\ F & \text { Viscous friction coefficient. }\end{array}$

\section{INTRODUCTION}

Nowadays, DFIGs are most popular for power generation, as they have high efficiency. The stator of the DFIG is connected to the power grid and the rotor is connected to the AC-DC-AC converter. Two control loops are applied to RSC and GSC individually [1].

The main purpose of this study is to perform the dynamic response of two different control techniques and evaluate the best response characteristics in the MPPT power curve by using the two control strategies. Generally, vector control is the most popular technique used in the DFIG-based wind turbines [2]. This control scheme using proportional-integral (PI) controllers [3]. In this control strategy, the decoupling between the q-axis and $\mathrm{d}$-axis current is achieved with feedforward compensation, and thus the DFIG model becomes less difficult and PI controllers can be used [4]. On the other hand, this control scheme gives more total harmonic distortion (THD), active power ripple, torque ripple and reactive power ripple of the DFIG-based wind turbines (WTSs)

To overcome the drawbacks of the vector control, a direct power control (DPC) has been presented [5-7]. The DPC is a simple and alternative approach control formulation that does not require decomposition into symmetrical components. In [8] a DPC control scheme of a single voltage source converter based on DFIG without using a rotor position sensor. In [9], an improved DPC control scheme of a wind turbine driven DFIGs connected to distorted grid voltage conditions was presented. In DPC control, two hysteresis controllers, namely active and reactive power controllers are selected to determine the inverter instantaneous switching state [10]. In [11], a modified DPC control scheme was proposed based on SFO control with a constant switching frequency, where a reference rotor voltage was calculated based on the estimated stator flux, reactive and active powers and their errors. In [12], reactive and active powers proportionalintegral controllers and SVM techniques were combined to replace the traditional hysteresis controllers. In [13], a DPC control was proposed based on the seven-level SVM technique to control DFIG-based wind turbines. In [14], a five-level DPC control scheme was proposed and compared to classical DPC strategy of DFIG-based WTS.

In this paper, the DPC control system with the application of the artificial neural networks (ANNs) controllers and new space vector pulse width modulation (SVPWM) has been considered. The original contribution of this paper is the application of the ANN controllers and new SVPWM technique in the DPC system with threephase induction generator (IG) and simulation investigation of this novel control system. The proposed scheme preserves the advantages of the DPC with PI controllers (DPC-PI) such as simplicity, less parameters dependence and fast response. In addition, axes transformation of the stator voltage or current is not required. Finally, the proposed and DPC-PI schemes 
performance is verified by the simulation study on the $1.5 \mathrm{MW}$ DFIG system under the variation of machine parameters.

\section{MODELING OF THE DFIG}

The equations of fluxes and voltages for the DFIG stator and rotor in Park orientation structure are given by [15-17]:

$\left\{\begin{array}{l}\mathrm{V}_{\mathrm{ds}}=\mathrm{R}_{\mathrm{s}} \mathrm{I}_{\mathrm{ds}}+\frac{\mathrm{d}}{\mathrm{dt}} \psi_{\mathrm{ds}}-\omega_{\mathrm{s}} \psi_{\mathrm{qs}} \\ \mathrm{V}_{\mathrm{qs}}=\mathrm{R}_{\mathrm{s}} \mathrm{I}_{\mathrm{qs}}+\frac{\mathrm{d}}{\mathrm{dt}} \psi_{\mathrm{qs}}+\omega_{\mathrm{s}} \psi_{\mathrm{ds}} \\ \mathrm{V}_{\mathrm{dr}}=\mathrm{R}_{\mathrm{r}} \mathrm{I}_{\mathrm{dr}}+\frac{\mathrm{d}}{\mathrm{dt}} \psi_{\mathrm{dr}}-\omega_{\mathrm{r}} \psi_{\mathrm{qr}} \\ \mathrm{V}_{\mathrm{qr}}=\mathrm{R}_{\mathrm{r}} \mathrm{I}_{\mathrm{qr}}+\frac{\mathrm{d}}{\mathrm{dt}} \psi_{\mathrm{qr}}+\omega_{\mathrm{r}} \psi_{\mathrm{dr}}\end{array}\right.$

Where : $\mathrm{V}_{\mathrm{dr}}$, and $\mathrm{V}_{\mathrm{qr}}$ are the rotor voltages.

$\mathrm{V}_{\mathrm{qs}}$ and $\mathrm{V}_{\mathrm{ds}}$ are the stator voltages.

$\mathrm{I}_{\mathrm{ds}}$ and $\mathrm{I}_{\mathrm{qs}}$ are the stator currents.

$\mathrm{I}_{\mathrm{dr}}$, and $\mathrm{I}_{\mathrm{qr}}$ are the rotor currents.

The stator and rotor flux can be expressed as:

$\left\{\begin{array}{l}\psi_{d s}=L_{s} I_{d s}+M I_{d r} \\ \psi_{q s}=L_{s} I_{q s}+M I_{q r} \\ \psi_{d r}=L_{r} I_{d r}+M I_{d s} \\ \psi_{q r}=L_{r} I_{q r}+M I_{q s}\end{array}\right.$

Where : $\mathrm{M}:$ is the mutual inductance.

$\psi_{\mathrm{dr}}$ and $\psi_{\mathrm{qr}}$ are the rotor fluxes.

$\psi_{\mathrm{ds}}$ and $\psi_{\mathrm{qs}}$ are the stator fluxes.

The reactive and active powers can be written as:

$\left\{\begin{array}{l}P_{s}=\frac{3}{2}\left(V_{d s} I_{d s}+V_{q s} I_{q s}\right) \\ Q_{s}=\frac{3}{2}\left(V_{q s} I_{d s}-V_{d s} I_{q s}\right)\end{array}\right.$

Where : $P_{s}$ : is the active power.

$\mathrm{Q}_{\mathrm{s}}$ : is the reactive power.
Where :

$\Omega:$ is the mechanical rotor speed.

$\mathrm{J}:$ is the inertia.

$\mathrm{T}_{\mathrm{r}}$ : is the load torque.

$\mathrm{f}:$ is the viscous friction coefficient.

And:

$T_{e m}=\frac{3}{2} p \frac{M}{L_{s}}\left(\psi_{q s} I_{d r}-\psi_{d s} I_{q r}\right)$

Where:

$\mathrm{p}$ : is the number of pole pairs.

$\mathrm{T}_{\mathrm{em}}$ : is the electromagnetic torque.

\section{DPC WITH PI CONTROLLER}

The DPC-PI goal is to control the magnitude of reactive and active powers of the DFIG-based wind turbine. In the DPC-PI, reactive power is connected using the direct axis voltage $\mathrm{V}_{\mathrm{dr}}$, while the active power is controlled using the quadrature axis voltage $\mathrm{V}_{\mathrm{qr}}$.

Stator active and reactive powers is estimated using (6) and (7) $[18,19]$.

$Q_{s}=-\frac{3}{2}\left(\frac{V_{s}}{\sigma . L_{s}} \cdot \varphi_{r \beta}-\frac{V_{s} \cdot L_{m}}{\sigma \cdot L_{s} \cdot L_{r}} \cdot \varphi_{r \alpha}\right)$

$P_{s}=-\frac{3}{2} \frac{L_{m}}{\sigma \cdot L_{s} \cdot L_{r}} \cdot\left(V_{s \cdot \varphi_{r \beta}}\right)$

The DPC-PI control scheme, which is designed to control the active and reactive power of the DFIG-based wind turbine, is shown in Fig. 1.

Where:

$$
\begin{aligned}
& \Psi_{s \alpha}=\sigma L_{r} I_{r \alpha}+\frac{M}{L_{s}} \Psi_{s} \\
& \sigma=1-\frac{M^{2}}{L_{r} L_{s}}
\end{aligned}
$$

$\Psi_{s \beta}=\sigma L_{r} I_{r \beta}$

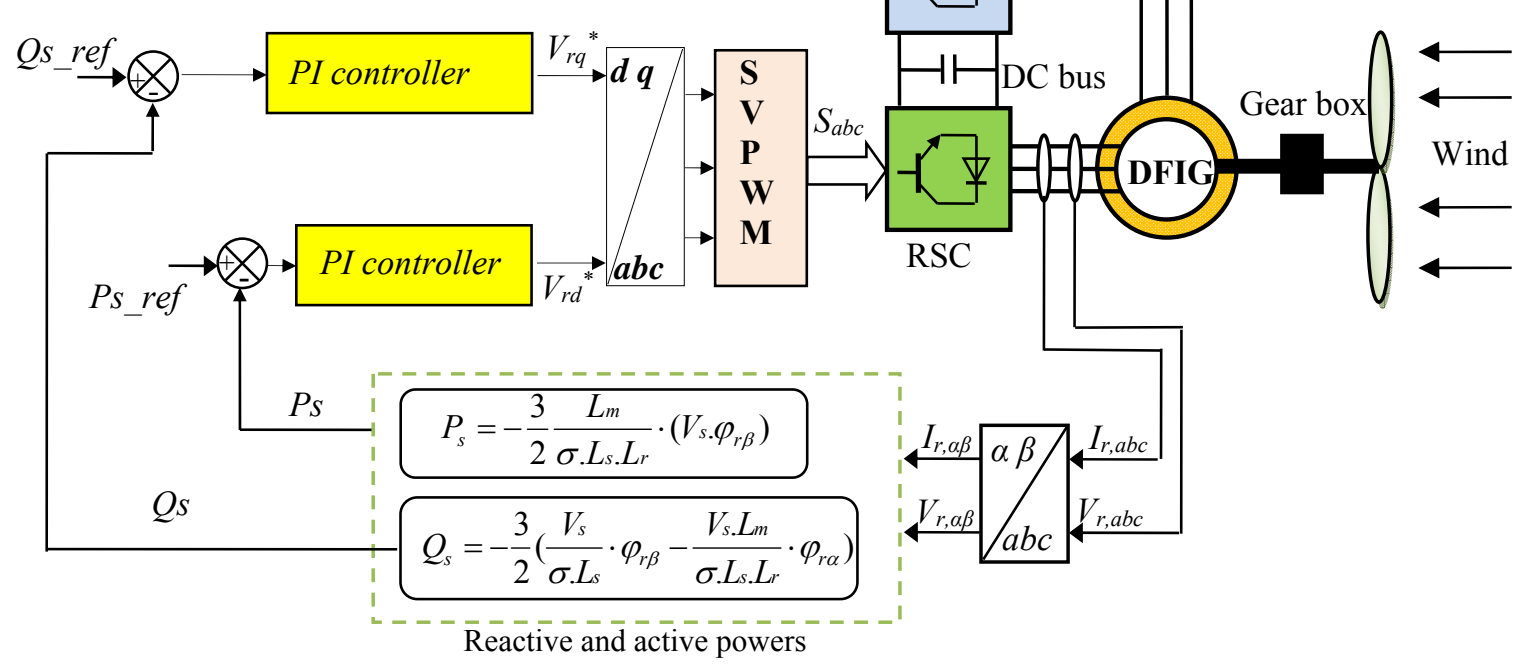

Fig. 1 DPC-PI control scheme 
The reactive and active powers can be reformulated by inducing angle $\lambda$ between the rotor and stator vectors as follows [20]:

$$
\begin{aligned}
& Q_{s}=-\frac{3}{2} \frac{w_{s}}{\sigma \cdot L_{s}}\left|\psi_{s}\right|\left(\frac{M}{L_{r}}\left|\psi_{r}\right| \cos (\lambda)-\mid \psi_{s}\right) \\
& P_{s}=-\frac{3}{2} \frac{L_{m}}{\sigma \cdot L_{r} \cdot L_{s}} \cdot w_{s} \cdot\left|\psi_{s}\right|\left|\psi_{r}\right| \cdot \sin (\lambda)
\end{aligned}
$$

The derivation of the active and reactive powers can given by:

$$
\begin{aligned}
& \frac{d Q_{s}}{d t}=-\frac{3}{2} \frac{M \cdot w_{s}}{\sigma \cdot L_{r} L_{s}}\left|\psi_{s}\right|\left(\frac{d\left(\left|\psi_{r}\right| \cos (\lambda)\right)}{d t}\right) \\
& \frac{d P_{s}}{d t}=-\frac{3}{2} \frac{L_{m}}{\sigma \cdot L_{s} \cdot L_{r}} w_{s}\left|\psi_{s}\right| \frac{d\left(\left|\psi_{r}\right| \sin (\lambda)\right)}{d t}
\end{aligned}
$$

On the other hand, the magnitude of stator flux, which can be estimated by:

$$
\left\{\begin{aligned}
\Psi_{s \alpha}= & \int_{0}^{t}\left(v_{s \alpha}-R_{s} i_{s \alpha}\right) d t \\
\Psi_{s \beta}= & \int_{0}^{t}\left(v_{s \beta}-R_{s} i_{s \beta}\right) d t
\end{aligned}\right.
$$

The stator flux amplitude is given by:

$\Psi_{S}=\sqrt{\Psi_{S \alpha}^{2}+\Psi_{s \beta}^{2}}$

Where:

$$
\left|\overline{\Psi_{s}}\right|=\frac{\left|\overline{V_{s}}\right|}{w_{s}}
$$

The stator flux angle is calculated by :

$$
\theta_{S}=\operatorname{arctg}\left(\frac{\Psi_{s \beta}}{\Psi_{S \alpha}}\right)
$$

\section{DPC WITH ANN CONTROLLER}

The DPC control scheme of a DFIG-based wind turbines with the application of the ANN controller is shown in Fig. 2. In this control system, the stator reactive and stator active powers are controlled by the ANN controller.

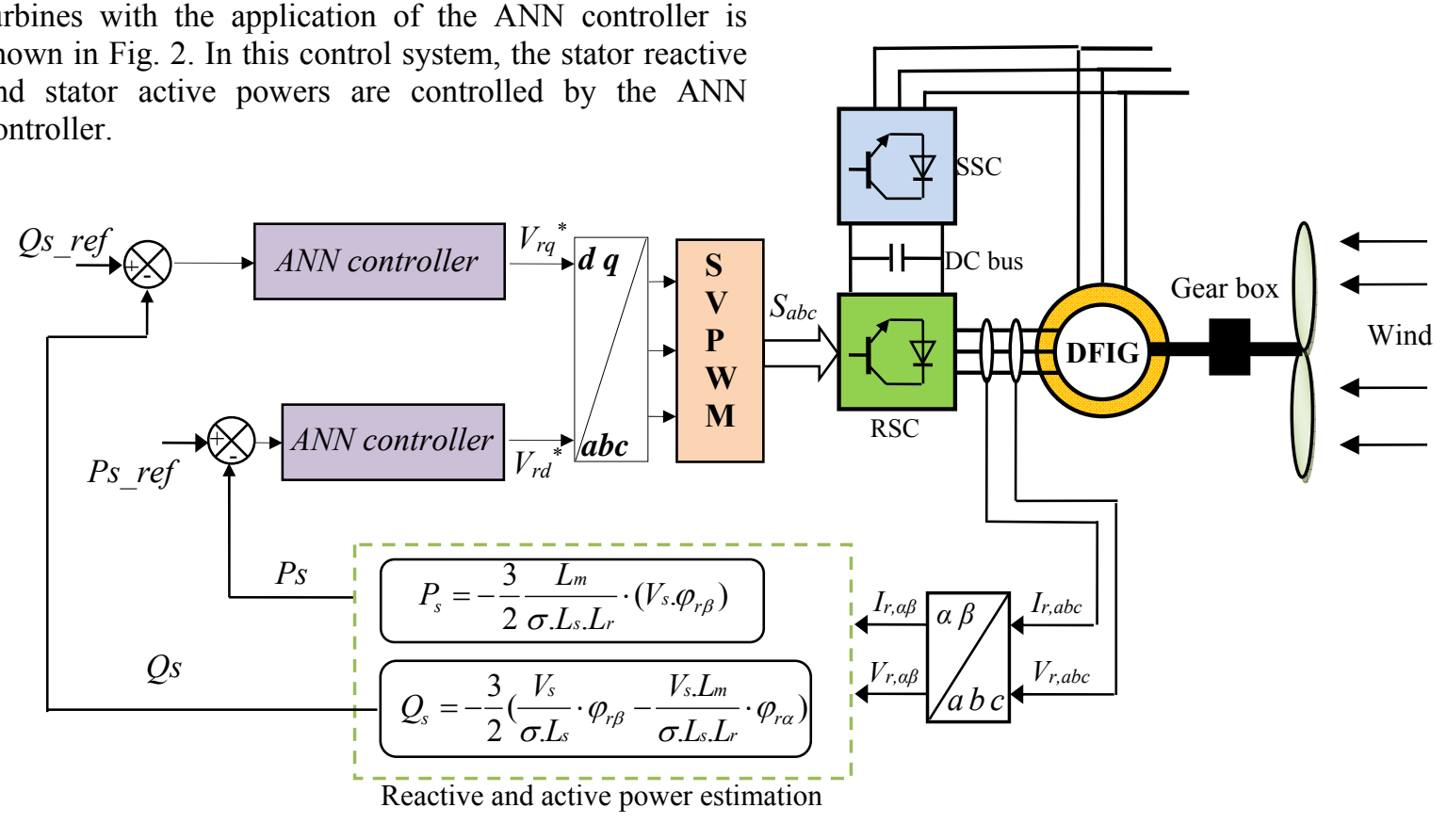

On the other hand, the DPC-ANN is similar to the DPC-PI control scheme. The difference is using an artificial neural networks (ANNs) controller to replace the classical PI controllers of active and reactive powers.

In recent years, ANN has become an interesting topic in the control studies. This controller is a part of the family of statistical learning techniques inspired by the biological nervous system and is used to estimate and approximate functions that depend only on a large number of inputs [21]. however, the ANN controller contains a hidden layer, input layer, and output layer. On the other hand, the number of the neurons in the output and input layers depends on the number of the selected output and input variables. This method based on NN control has the advantage of simplicity and easy implementation. The construction of the $\mathrm{NN}$ regulator to realize the classical PI controllers applied to DPC control was an ANN controller with one linear input node, 8 neurons in the hidden layer, and one neuron in the output layer, as shown in Fig. 3. The construction of Layer 1, layer 2 and the hidden layer are shown in Fig. 4, Fig. 5 and Fig. 6 respectively. The convergence of the ANN controllers in summer obtained by using the value of the parameters grouped in Table 1. On other hand, the training used is that of the algorithm, Gradiant descent with momentum \& Adaptive LR.

Table 1 Parameters of the neural controller

\begin{tabular}{|l|c|}
\hline \multicolumn{1}{|c|}{ Parameters } & Values \\
\hline Number of hidden layer & 08 \\
\hline TrainParam.Lr & 0.005 \\
\hline TrainParam.show & 50 \\
\hline TrainParam.eposh & 1000 \\
\hline $\begin{array}{l}\text { Coeff of acceleration of } \\
\text { convergence (mc) }\end{array}$ & 0.9 \\
\hline TrainParam.goal & 0 \\
\hline TrainParam.mu & 0.9 \\
\hline Functions of activation & $\begin{array}{c}\text { Tensing, Purling, } \\
\text { gensim }\end{array}$ \\
\hline
\end{tabular}

\footnotetext{
(1)

(1)
}

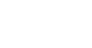

Fig. 2 DPC-ANN control scheme 


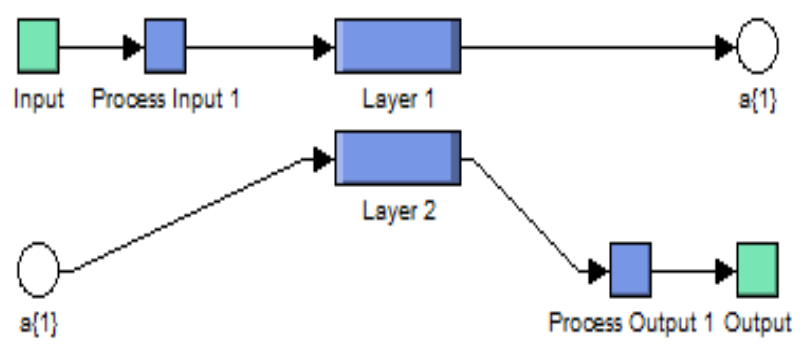

Fig. 3 Neural network structure for SVPWM technique

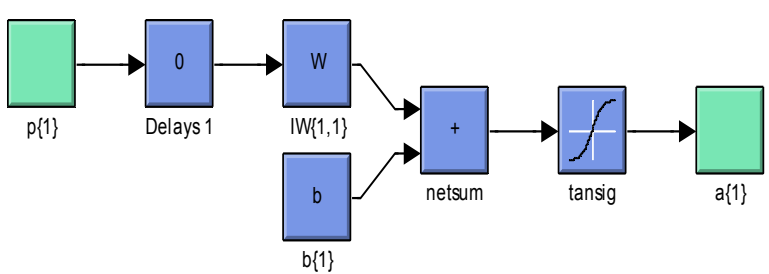

Fig. 4 Architecture of Layer 1

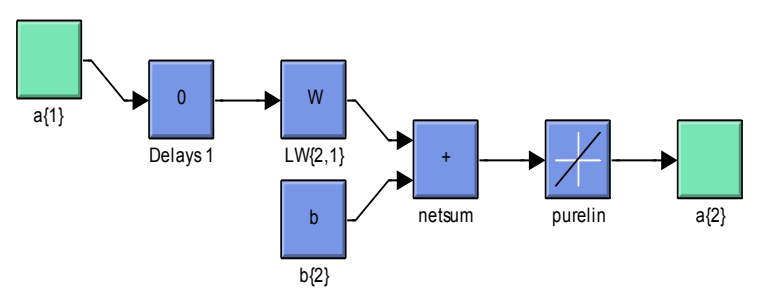

Fig. 5 Architecture of Layer 2

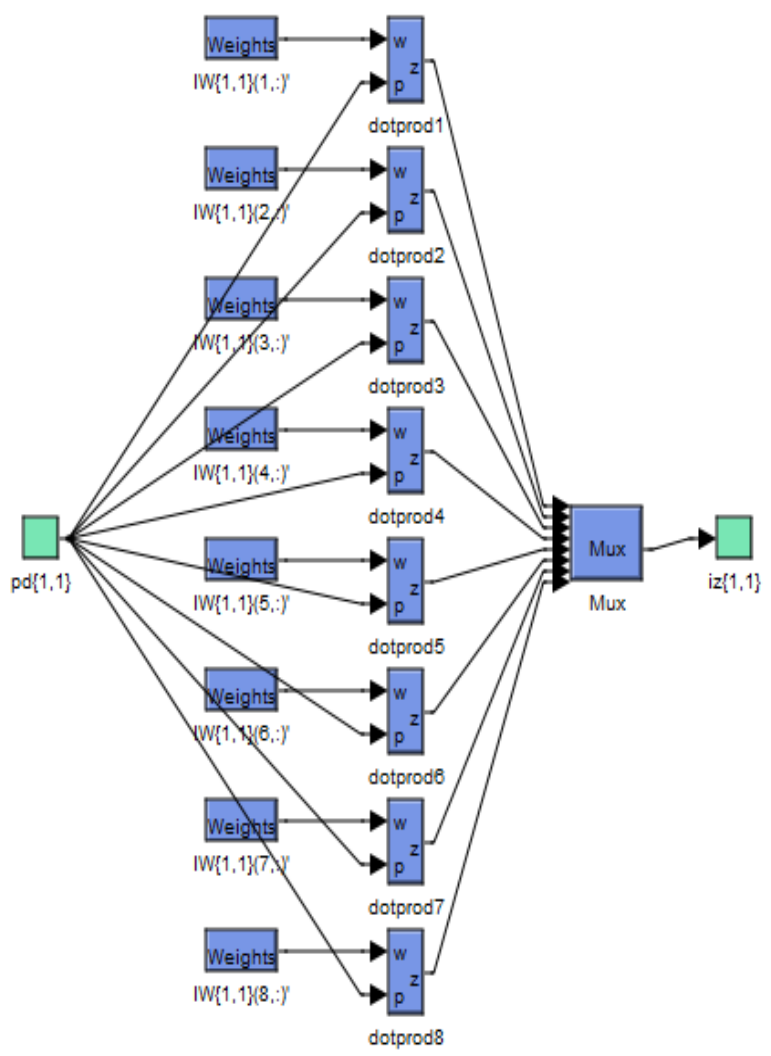

Fig. 6 Hidden layer

\section{RESULTS AND ANALYSIS}

The simulation results of DPC with ANN controllers of the DFIG are compared with the DPC-PI strategy. To this end, the control system was tested under deferent tests such as robustness tests. The performance analysis is done with active power, electromagnetic torque, harmonic distortion of stator current and reactive power.

The DFIG used in this case study is a $1.5 \mathrm{MW}$, $380 / 696 \mathrm{~V}$, two poles, $50 \mathrm{~Hz}$; with the following parameters: $\mathrm{Rs}=0.012 \Omega, \mathrm{Rr}=0.021 \Omega, \mathrm{Ls}=0.0137 \mathrm{H}$, $\mathrm{Lr}=0.0136 \mathrm{H}$ and $\mathrm{Lm}=0.0135 \mathrm{H}$.

The system has the following mechanical parameters: $\mathrm{J}=1000 \mathrm{~kg} . \mathrm{m} 2, \mathrm{fr}=0.0024 \mathrm{Nm} / \mathrm{s}[22,23]$.

\section{A. Reference tracking test (RTT)}

Figs. 7-8 show the THD of the stator current of the DFIGbased wind turbine obtained using the FFT (Fast Fourier Transform) strategy for DPC strategy with ANN controllers (DPC-ANN) and DPC-PI one respectively. It can be clearly observed that the THD is minimized for the DPC-ANN control scheme (THD $=1.09 \%$ ) when compared to DPC-PI $(\mathrm{THD}=0.88 \%)$. Figs 9-12 show the obtained simulation results. For the DPC-ANN and DPCPI control scheme, the stator active and reactive powers track almost perfectly their reference values. Moreover, the DPC-ANN control scheme minimized the stator active power ripple, stator current ripple, and reactive power ripple compared to the DPC-PI (See Figs. 13-16).
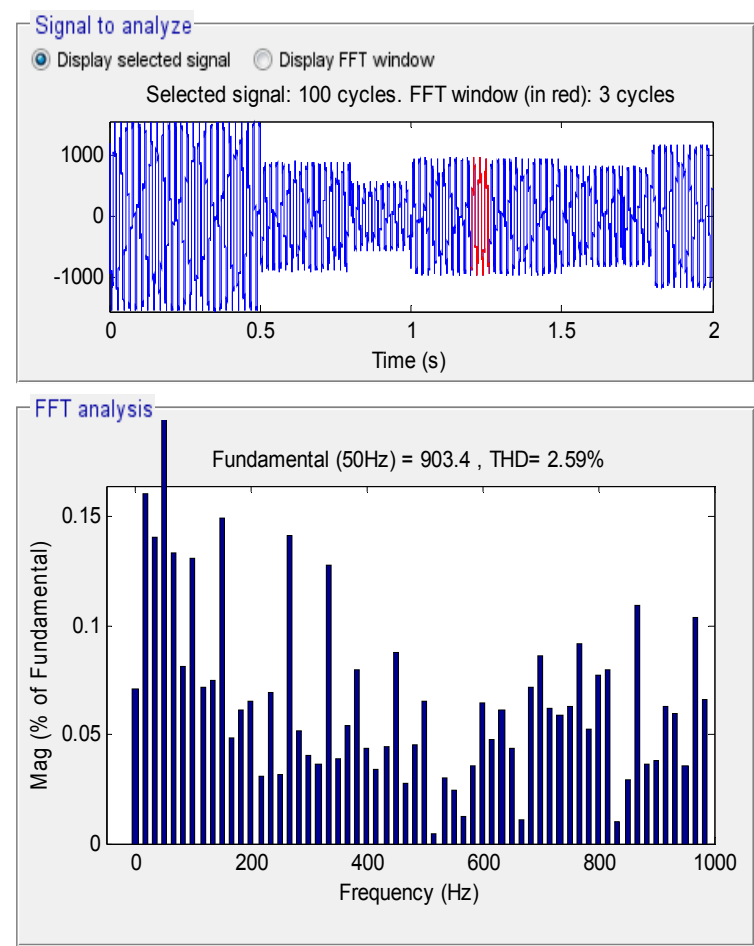

Fig. 7 Spectrum harmonic of stator current (DPC-PI) 

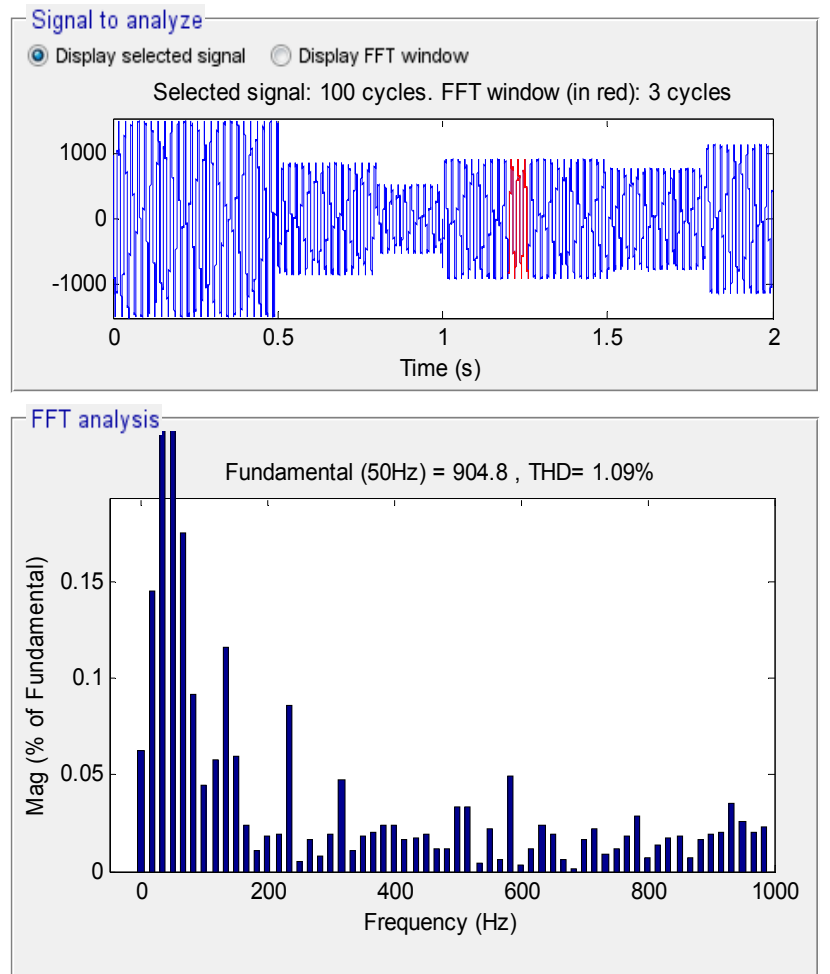

Fig. 8 Spectrum harmonic of stator current (DPC-ANN)

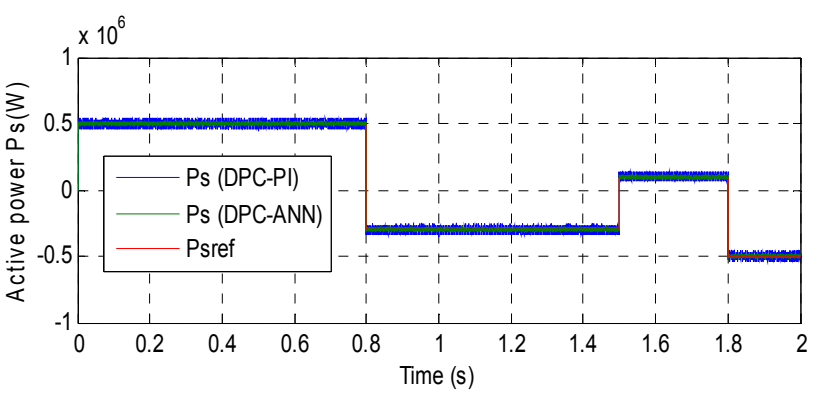

Fig. 9 Active power (RTT)

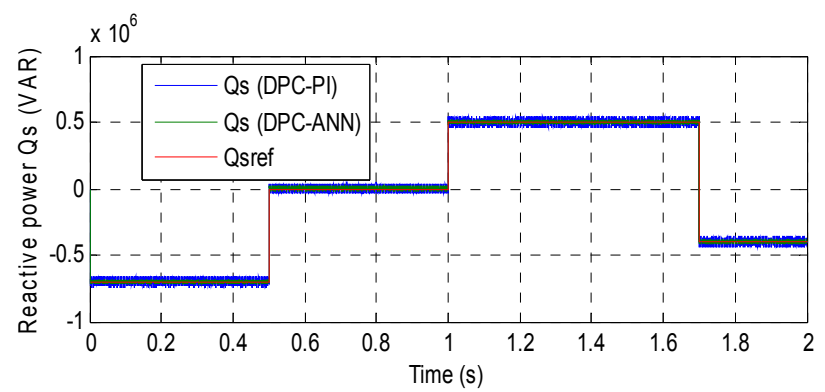

Fig. 10 Rective power (RTT)

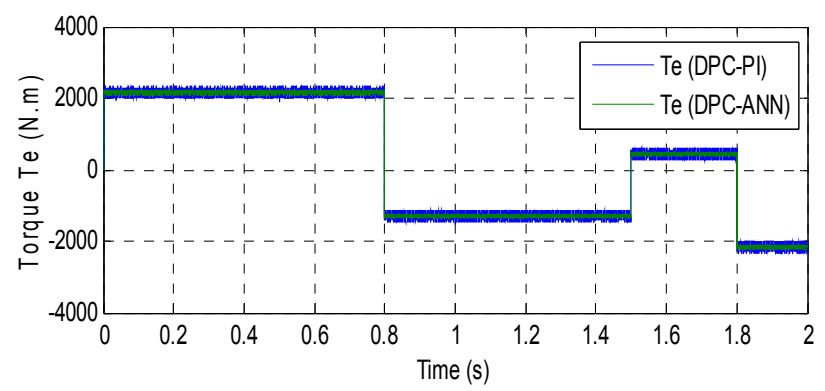

Fig. 11 Torque (RTT)

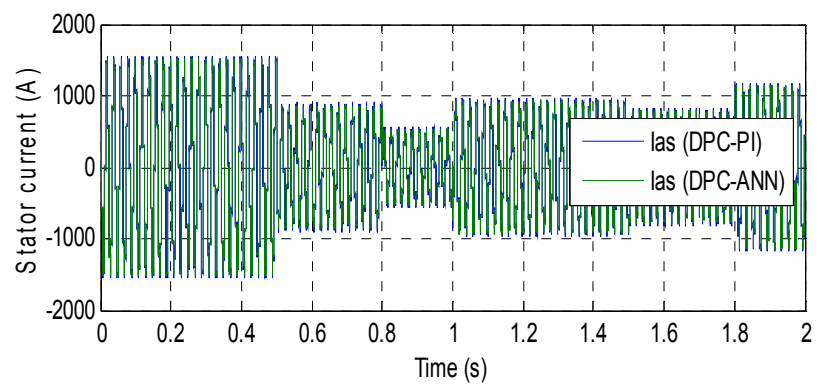

Fig. 12 Stator current Ias (RTT)

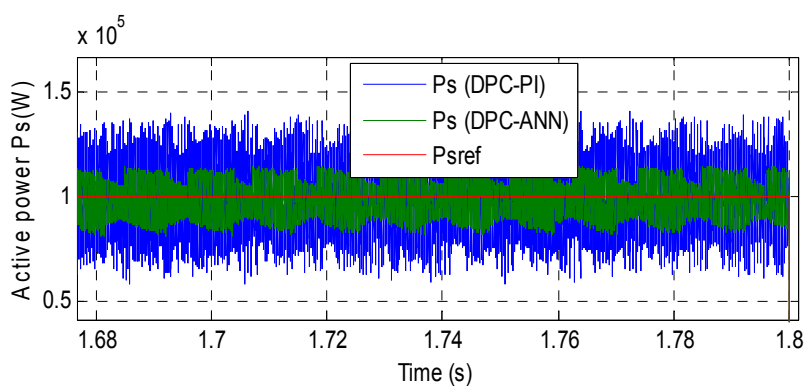

Fig. 13 Zoom in the active power (RTT)

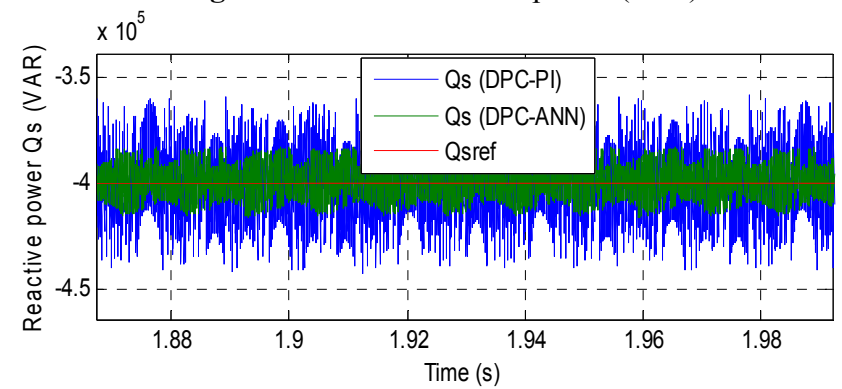

Fig. 14 Zoom in the reactive power (RTT)

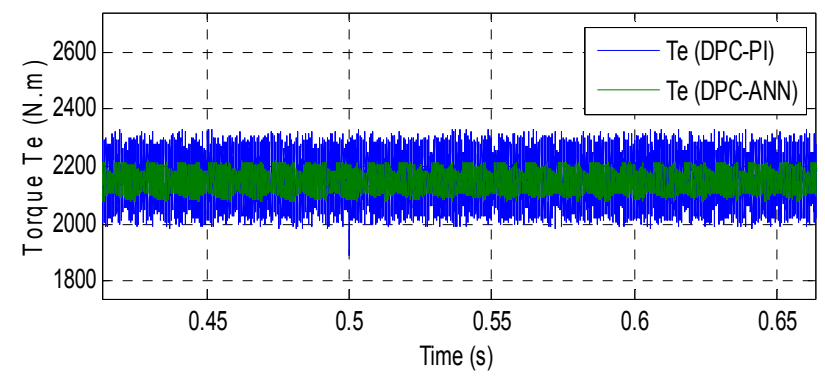

Fig. 15 Zoom in the torque (RTT)

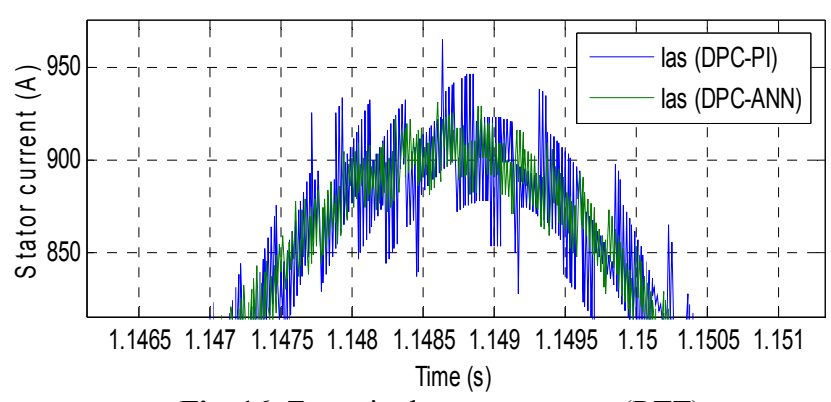

Fig. 16 Zoom in the stator current (RTT)

\section{B. Robustness test (RT)}

In this section, the nominal value of the $R_{r}$ and $R_{s}$ is multiplied by 2. Simulation results are presented in Figs 17-22. As it's shown by these figures, these variations present an apparent effect on the torque, stator current, 
stator reactive and active powers curves and that the effect appears more significant for the DPC-PI control scheme compared to DPC-ANN (See Figs. 23-26).

The THD value of stator current in the DPC-ANN control has been minimized significantly (See Figs 17-18). Table 2 shows the comparative analysis of THD value. Thus it can be concluded that the proposed DPC with ANN controllers is more robust than the DPC-PI strategy.

Table 2 Comparative analysis of THD value (RT)

\begin{tabular}{|l|c|c|}
\cline { 2 - 3 } \multicolumn{1}{c|}{} & \multicolumn{2}{c|}{ THD (\%) } \\
\cline { 2 - 3 } \multicolumn{1}{c|}{} & DPC-PI & DPC-ANN \\
\hline Rotor current & 5.39 & 2.42 \\
\hline
\end{tabular}
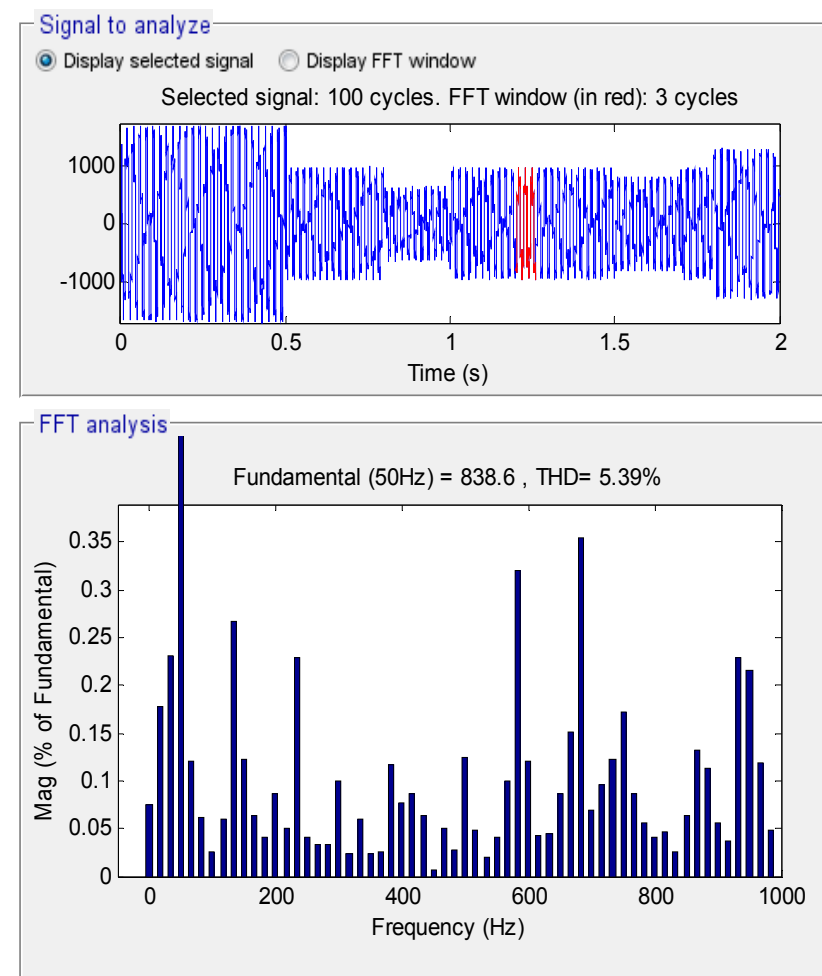

Fig. 17 Spectrum harmonic of stator current (DPC-PI)
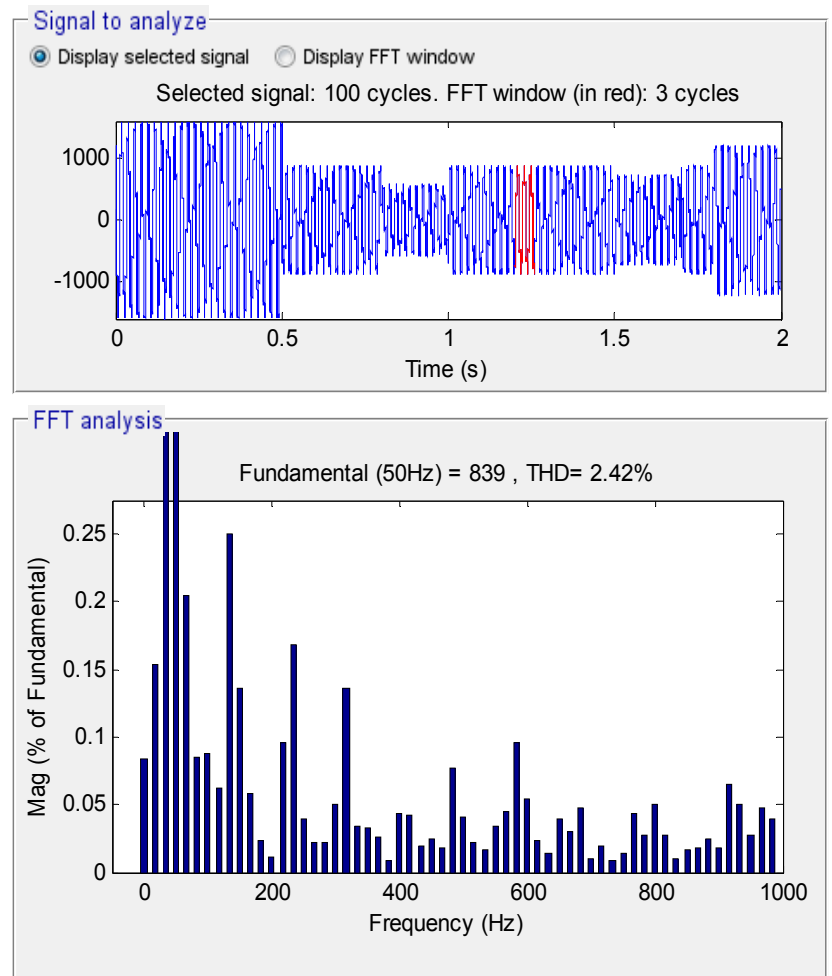

Fig. 18 Spectrum harmonic of stator current (DPC-ANN)

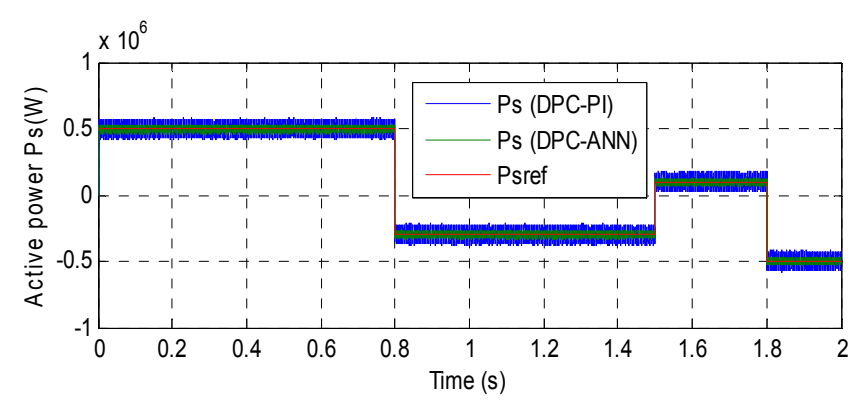

Fig. 19 Active power (RT)

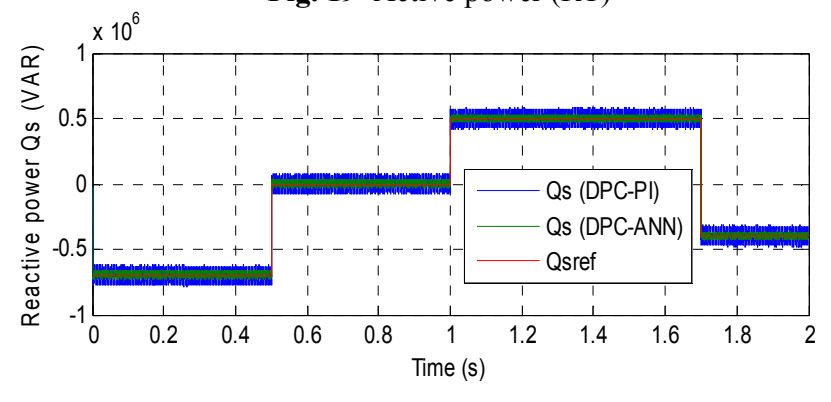

Fig. 20 Reactive power (RT)

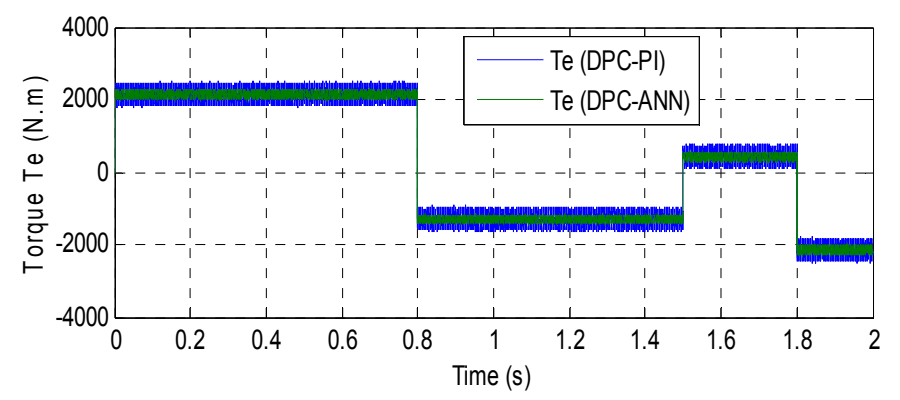

Fig. 21 Torque (RT) 


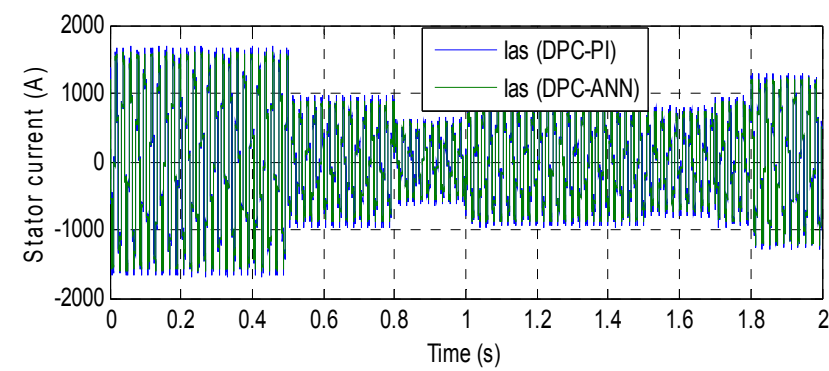

Fig. 22 Stator current (RT)

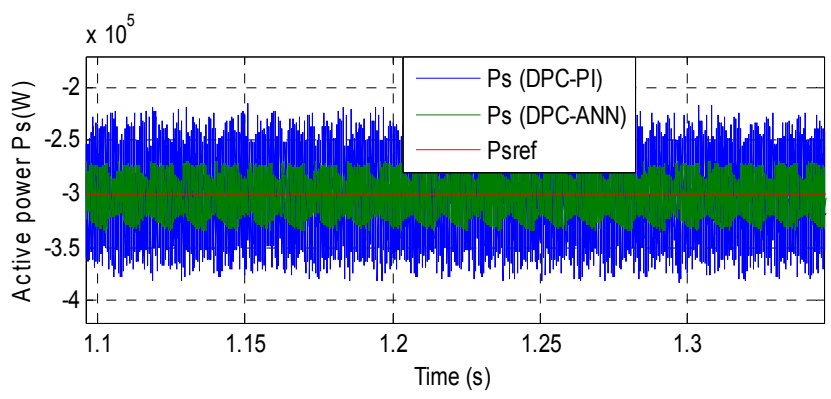

Fig. 23 Zoom in the active power (RT)

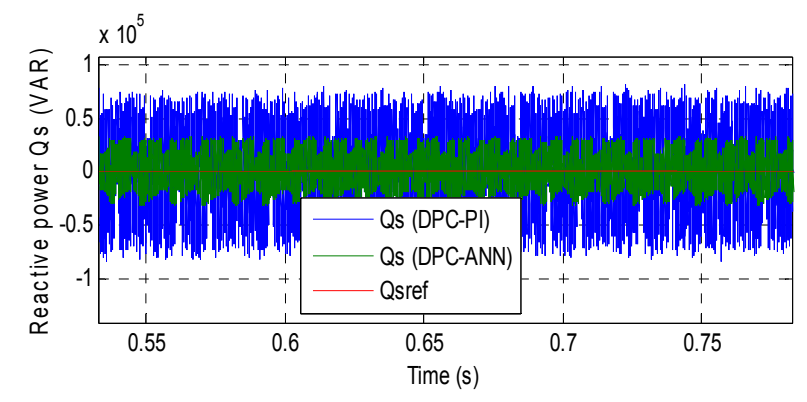

Fig. 24 Zoom in the reactive power (RT)

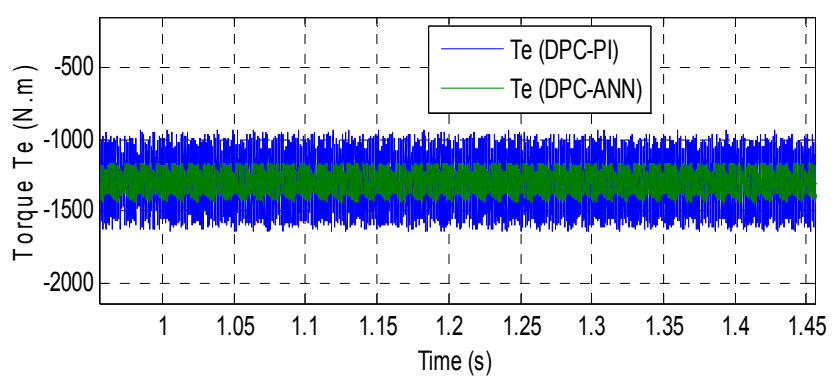

Fig. 25 Zoom in the torque (RT)

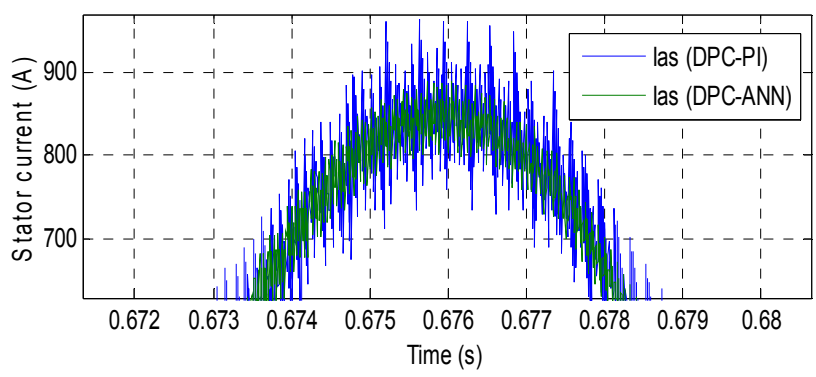

Fig. 26 Zoom in the stator current (RT)

\section{CONCLUSION}

In this article, we presented the DPC strategy with the ANN controllers of the stator active and reactive powers of the DFIG supplied by the SVPWM strategy at twolevel. A DPC with the ANN controller is synthesized and compared to DPC using traditional PI controllers. The simulation results show that the DPC with ANN controllers is an excellent solution for DFIG based wind turbines. In terms of tracking performances reactive and active powers references, and THD of stator current. Furthermore, the obtained results have approved that the DPC with ANN controllers minimizes the THD value of stator current, and powers ripples more and more than the DPC using classical PI controllers.

\section{REFERENCES}

[1] WA, Y. - YANG, W.: Different control strategies on the rotor side converter in DFIG-based wind turbines, Energy Procedia, Elsevier, Vol. 100, pp. 551-555, 2016.

[2] AMRANE, F. - CHAIBA, A. - BABAS, B. MEKHILEF, S.: Design and implementation of high performance field oriented control for gridconnected doubly fed induction generator via hysteresis rotor current controller, Rev. Roum. Sci. Techn.-Electrotechn. Et Energ, Vol. 61, No. 4, pp. 319-324, 2016.

[3] AMRANE, F. - CHAIBA, A.: A novel direct power control for grid-connected doubly fed induction generator based on hybrid artificial intelligent control with space vector modulation, Rev. Roum. Sci. Techn.-Electrotechn. Et Energ, Vol. 61, No. 3, pp. 263-268, 2016.

[4] BOUDJEMA, Z. - TALEB, R. - DJERRIRI, Y. YAHDOU, A.: A novel direct torque control using second order continuous sliding mode of a doubly fed induction generator for a wind energy conversion system, Turkish Journal of Electrical Engineering \& Computer Sciences, Vol. 25, pp. 965-975, 2017.

[5] JOU, S. - LEE, S. - PARK, Y. - LEE, K.: Direct Power Control of a DFIG in Wind Turbines to Improve Dynamic Responses, Journal of Power Electronics, Vol. 9, No. 5, pp. 781-790, 2009.

[6] TAVAKOLI, S. M. - POURMINA, M. A. ZOLGHADRI, M.R.: Comparison between different DPC methods applied to DFIG wind turbines, International Journal of Renewable Energy Research, Vol. 3, No. 2, pp. 446-452, 2013.

[7] MIRZAKHANI, A. - GHANDEHARI, R. DAVARI, S. A.: A New DPC-based Control Algorithm for Improving the Power Quality of DFIG in Unbalance Grid Voltage Conditions, International Journal Of Renewable Energy Research, Vol. 8, No. 4, pp. 2229-2238, 2018. 
[8] SINGH, B. - NAIDU, N. K. S.: Direct power control of single VSC-based DFIG without rotor position sensor, IEEE Transactions on Industry Applications, Vol. 50, No. 6, 2014.

[9] SHEHATA, E. G. - SAlAMA, G. M.: Direct power control of DFIGs based wind energy generation systems under distorted grid voltage conditions, Electr. Power Energy Syst. Vol. 53, pp. 956-966, 2013.

[10] SHEHATA, E. G.: Sliding mode direct power control of RSC for DFIGs driven by variable speed wind turbines, Alexandria Engineering, 2015.

[11] ZHI, D. - XU, L.: Direct power control of DFIG with constant switching frequency and improved transient performance, IEEE Trans. Energy Convers, Vol. 22, Vol. 1, pp. 110-118, 2007.

[12] JOU, S. - LEE, S. - PARK, Y. - LEE, K.: Direct power control of a DFIG in wind turbines to improve dynamic responses, J. Power Electron, Vol. 9, No. 3, pp. 781-790, 2009.

[13] BENBOUHENNI, H.: Direct Power Control of a DFIG Fed by a Seven-Level Inverter Using SVM Strategy, International Journal of Smart, Vol. 3, No. 2, pp. 54-62, 2019.

[14] BENBOUHENNI, H.: Application of five-level NPC inverter in DPC-ANN of doubly fed induction generator for wind power generation systems, International Journal of Smart Grid, Vol. 3, No. 3, pp. 129-137, 2019.

[15] BENBOUHENNI, H. - BOUDJEMA, Z. BELAIDI, A.: Direct vector control of a DFIG supplied by an intelligent SVM inverter for wind turbine system, Iranian Journal of Electrical and Electronic Engineering, Vol. 15, No. 1, pp. 45-55, 2019.

[16] BENBOUHENNI, H. - BOUDJEMA, Z. BELAIDI, A.: Direct vector command based on three-level NSVM of a doubly fed induction generator for wind energy conversion, IEEE Xplore, 2019.

[17] BENBOUHENNI, H. - BOUDJEMA, Z. BELAIDI, A.: DFIG-based wind turbine system using three-level neural space vector modulation technique, Majlesi Journal of Mechatronic Systems, Vol. 7, No. 2, pp. 35-45, 2018.

[18] BENBOUHENNI, H. - BOUDJEMA, Z.: Two-level DTC based on ANN controller of DFIG using 7level hysteresis command to reduce flux ripple comparing with traditional command, IEEE Xplore, 2019.
[19] NAZARI, A. - HEYDARI, H.: Direct Power Control Topologies for DFIG-Based Wind Plants, International Journal of Computer and Electrical Engineering, Vol. 4, No. 4, pp. 475-479, 2012.

[20] NIAN, H. - SONG, Y.: Direct power control of doubly fed induction generator under distorted grid voltage, IEEE Transactions on Power Electronics, Vol. 29, No. 2, pp. 894-905, 2014

[21] BENBOUHENNI, H.: Seven-level direct torque control of induction motor based on artificial neural networks with regulation speed using fuzzy PI controller, Iranian Journal of Electrical and Electronic Engineering, Vol. 14, No.1, pp. 85-94, 2018.

[22] BENBOUHENNI, H.: Stator active and reactive power ripples minimization for DVC control of DFIG by using five-level neural space vector modulation, Acta Electrotechnica et Informatica, Vol. 19, No. 2, pp. 16-23, 2019.

[23] BENBOUHENNI, H.: Fuzzy second order sliding mode controller based on three-level fuzzy space vector modulation of a DFIG for wind energy conversion systems, Majlesi Journal of Mechatronic Systems, Vol. 7, No. 3, 2018.

Received September 27, 2019, accepted October 24, 2019

\section{BIOGRAPHIES}

Habib Benbouhenni was born in chlef, Algeria. He is a $\mathrm{PhD}$ student in the Departement of electrical engineering at the ENPO-MA, Oran, Algeria. He received a M.A. degree in Automatic and informatique industrial in 2017. His research activities include the application of robust control in the wind turbine power systems.

Zinelaabidine Boudjema was born in Algeria in 1983. $\mathrm{He}$ is Teacher in university of chlef, Algeria. He received a M.S. degree in electrical engineering from ENP of Oran, Algeria in 2010. He received a $\mathrm{PhD}$ in Electrical Engineering from university of Sidi Belabes, Algeria 2015. His research activities include the study and application of robust control in the wind-solar power systems.

Abdelkader Belaidi, Professor at the National Polytechnic High School - Maurice Audin in Oran. He obtained his Ph.D in Physics at the University Of East Anglia - UK in 1980. His current fields of interest are Nanotechnology, robototics and Artificial Intelligence. 